\title{
Research Paper Problems in production and marketing of caulifower in Belgaum district of Karnataka
}

\section{- ROOPA HOSALI AND SAMEER LOKAPUR}

See end of the paper for authors' affiliations

Correspondence to :

ROOPA HOSALI

Department of

Agribusiness Management,

College of Agriculture,

University of Agricultural

Sciences, DHARWAD

(KARNATAKA) INDIA

Email:roopa.hosali88@gmail. com

Paper History :

Received : 01.01.2015;

Revised : 21.01.2015;

Accepted : 07.02.2015
ABSTRACT : Vegetables are rich and comparatively cheaper sources of vitamins. India stands as the largest producer of vegetables in the world after China; it contributes over 13 per cent to the world's vegetable production.In India stands as the largest producer of cauliflower in the world after China. The area under cauliflower in India during 2013-14 has been reported as 402.1 thousand /hectare with a production of 7887 thousand M.T. In Karnataka cauliflower having area 4.90 thousand /hectare. The study aimed to analyze the Problems in production and marketing of cauliflower in Belgaum district of Karnataka which has a high concentration of area under vegetables and recognized as cauliflower market in the state. The primary data on problems faced by farmer production and marketing of cauliflower in Belgaum district. Among the seven problems considered, non-availability of labour was the major problem expressed by most of the respondents. High incidence of pest and diseases was another serious problem as experienced by many respondents. The seeds of high yielding varieties are usually priced high. Farmers comparing the prices of the local grown and owned seed material and opining that the planting material cost as high is quite obvious. The sample farmers revealed that as such there were problems in marketing of cauliflower and are many. Among them top seven problems considered for analysis. Garrett's ranking technique revealed that with respect to marketing problems poor transportation facility was the most important. Non-availability unit of standard measurement and faulty weighment especially in vegetable (cauliflower) marketing was another problem expressed by them and a cause for poor income. High commission charge was another major problem. Fluctuation in the prices of cauliflower and non availability of market related information on daily cauliflower market condition is another important problem as perceived by majority of the farmers. The problems faced by the intermediaries were more or less similar to the problems faced by the farmers. The suggestion discussed above to reduce the marketing problems faced by the producers can take care the problems faced by market intermediaries. However, to combact volatitlity demand situation market grid for cauliflower can be thought of at state or national level to transfer the commodities from stock areas or surplus areas to deficit areas to ease out the situation.

KEY WORDS : Production, Marketing, Caulifower

HOW TO CITE THIS PAPER : Hosali, Roopa and Lokapur, Sameer (2015). Problems in production and marketing of caulifower in Belgaum district of Karnataka. Internat. Res. J. Agric. Eco. \& Stat., 6 (1) : 113-117. 